\title{
Prevalence and Characterization of Shiga Toxin-Producing Escherichia coli Isolated from Slaughtered Qurban Animal in Jakarta Province
}

\author{
S. G. Ningrum*, R. D. Soejoedono, H. Latif, W. Arnafia, \& I. W. T. Wibawan \\ Department of Animal Disease and Veterinary Public Health, Faculty of Veterinary Medicine, \\ Bogor Agricultural University \\ Jalan Agatis, Kampus IPB Darmaga Bogor 16680, Indonesia \\ (Received 11-03-2016; Reviewed 08-04-2016; Accepted 24-06-2016)
}

\begin{abstract}
This study was conducted to investigate the presence of shiga toxin producing Escherichia coli (STEC) and the possibility of carrying $r f b E$ gene and $\mathrm{H} 7$ flagellar on meat, liver, and stool samples collected from Jakarta Province of Indonesia. A total of 51 samples collected from meat, liver, and stool of slaughtered cattle from qurban festival were tested using conventional culture and multiplex PCR methods. STEC non $\mathrm{O} 157$ were detected in meat $(5.3 \%)$ and stool $(8.3 \%)$ with one isolate from stool carried H7 flagellar. However, all isolates were lacking of $r f b E$ gene. In antimicrobial susceptibility tests, the STEC isolates showed antibiotic resistance to erythromycin and oxacillin. Overall, the result shows that meat and liver of this origin activity represents a potential risk to human health.
\end{abstract}

Key words: STEC, multiplex PCR, meat, feces, antimicrobial

\begin{abstract}
ABSTRAK
Penelitian ini bertujuan untuk menginvestigasi keberadaan Escherichia coli penghasil racun shiga (STEC) dan kemungkinan adanya gen $r f b E$ dan flagella $\mathrm{H} 7$ pada strain yang ditemukan di dalam sampel daging, hati dan feses yang diisolasi dari provinsi Jakarta, Indonesia. Sejumlah 51 sampel dikoleksi dari daging, hati dan feses sapi yang dipotong pada hari raya kurban diuji menggunakan metode konvensional kultur dan multiplex PCR. Hasil studi menunjukkan STEC non-O157 terdeteksi di daging $(5,3 \%)$ dan feses $(8,3 \%)$ sapi dengan satu isolat terdeteksi membawa flagela H7. Akan tetapi, semua isolat tidak membawa gen $r f b E$. Sensitivitas bakteri terhadap berbagai antibiotik juga diuji dalam penelitian ini. Isolat STEC menunjukkan sifat resisten terhadap eritromisin dan oxacilin. Secara keseluruhan, hasil penelitian ini menunjukkan adanya potensi cemaran STEC pada daging dan hati hewan kurban dalam studi ini yang dapat mengancam kesehatan masyarakat.
\end{abstract}

Kata kunci: STEC, multiplex PCR, daging, feses, antimikroba

\section{INTRODUCTION}

Shiga toxin-producing Escherichia coli (STEC) are major food-borne pathogens, which are well known of producing Shiga toxin type 1 (Stx1), type 2 (Stx2), or both, encoded by the genes of stx 1 and st 2 , respectively (Sharma, 2006; Torres et al., 2006). The Stxs are AB5 toxins that inhibit protein synthesis in the host cell. This process may lead to an apoptotic cell death, especially to a damage of renal glomerular endothelial cells (Melton-Celsa et al., 2012; Xicohtencatl-cortes et al., 2007). Stx 2 is the toxin type most related to hemolytic uremic syndrome (HUS). Hemolytic uremic syndrome is characterized by acute renal failure, thrombocytopenia, and microangiopathic hemolytic anemia and is a poten-

*Corresponding author:

E-mail: $\underline{\text { sitiningrum10@gmail.com }}$ tially fatal cause of acute renal failure in children (Rahal et al., 2012). Deaths have been reported more frequently with O157:H7-induced HUS but might also occur with non-O157 STEC-induced HUS (Frank et al., 2011; Lim et al., 2010). Until now, there is no treatment for HUS and use of antimicrobial agents is contraindicative (Nguyen \& Sperandio, 2012).

Qurban festival is a religious festival in which animals are sacrificed, including cattle, goat, and sheep. In developing countries such as Indonesia, these activities are often constrained by the limitations of facilities and skilled human resources. In addition, most of the slaughter of sacrificial animals to date is done by people outside the abattoir, like in the courtyard of the mosque or on private or government field offices, generally at the center of settlements. Although all activities are already under the supervision of a veterinarian or health workers appointed by the competent authority, nothing is known about a pathogenic microbial contamination in 
the slaughter process. Therefore, at present no information is available about pathogenic bacteria, especially STEC contamination in Qurban festival. Cattle are the main reservoir of STEC, where the organism typically colonizes the lower gastrointestinal tract and shed the bacteria through their feces (Inat \& Siriken, 2010; Perera et al., 2015). Also, cattle has a significant proportion of beef become contaminated during slaughter (Kundu et al., 2014). In Indonesia, satay is a popular undercooked meat and will become a problem when the meat is contaminated by STEC. It is suggested that meat may be an important transmission vehicle for this food-borne pathogen. Previous study (Selim et al., 2013) also indicated that an increasing number of strains are showing a multiresistance to a number of antibiotics. To address this, the present study was designed to investigate the presence of STEC in the meat, liver and bovine stools sample in Qurban festival in Jakarta Province of Indonesia by considering the possibility of STEC O157:H7 presence. The above isolates were additionally studied for virulence characteristics and antimicrobial susceptibility.

\section{MATERIALS AND METHODS}

\section{Bacterial Strains}

This study used 2 E. coli O157:H7 strains as control. Both strains, producing Stx1 and Stx2 were obtained from American Type Culture Collection (ATCC) 35150 and Bogor Agricultural University (BAU), respectively.

\section{Study Design for Purposive Sampling}

Purposive sampling was chosen in this study. A total of 51 samples including 19 meat, 20 liver and 12 fecal samples were collected from five different mosques in Jakarta in October 2014. The geographical distribution of the five mosques is depicted in Figure 1. At each mosque, all cattles were selected. It was made to ensure that fecal, liver and meat samples were from exactly the same animals. The investigations on this study are minor influenced by the sampling method adopted (Wang et al., 1996).

\section{Sampling and Bacterial Culture Methods for Feces, Liver and Meat}

The procedure of culture method was based on a previous method with minor modification (Selim et al., 2013). As many as $250 \mathrm{~g}$ of meat, liver and fecal samples respectively, were taken into an aseptic plastic bag and placed in an ice box. Upon arrival at the laboratory, the samples were held at $4^{\circ} \mathrm{C}$, not longer than $24 \mathrm{~h}$ before analysis. About $25 \mathrm{~g}$ of each sample was placed aseptically in a stomacher bag with $225 \mathrm{~mL}$ phosphate buffered saline (PBS) 0.1\% (Oxoid, UK) and mixed for $1 \mathrm{~min}$. Each sample $(1 \mathrm{~mL})$ was transferred into $50 \mathrm{~mL}$ of brain heart infusion (BHI) broth (Oxoid, UK) for enrichment and incubated at $37^{\circ} \mathrm{C}$ for $24 \mathrm{~h}$. After the enrichment procedure, one loop of the broth was inoculated onto eosin methylene blue agar (EMB) (Oxoid, UK) for selec- tive and differential procedures. After 24 h- incubation at $37^{\circ} \mathrm{C}$, up to two purple coloured colonies with green metallic sheen were transferred onto cefixime-tellurite sorbitol MacConkey (CT-SMAC) (Oxoid, UK) agar and incubated at $37^{\circ} \mathrm{C}$ for $24 \mathrm{~h}$. SMAC agar is recommended for the isolation of pathogenic STEC O157. STEC O157 does not ferment sorbitol and therefore produces colourless colonies. In contrast, most of non STEC O157 ferment sorbitol and form pink colonies. Those identified as STEC O157 in CT-SMAC were subjected for the presence of virulence genes by multiplex PCR.

\section{Characterization of STEC}

The E. coli strains isolated in this study and the STEC O157 reference were cultured on $7 \%$ sheep blood agar (Oxoid, UK) for cultivation. After overnight culture, colonies from each plate were inoculated into $\mathrm{BHI}$, and the broth was incubated at $37^{\circ} \mathrm{C}$ for 24 $\mathrm{h}$ prior to nucleic acid extraction. The broth cultures were centrifuged at 4,500 $\mathrm{g}$ for $15 \mathrm{~min}$ in a Biofuge pico (Heraeus, Hanau, Germany), the supernatant was discarded, the pellet was washed three times with 10 $\mathrm{mL}$ of phosphate buffered saline (PBS; pH 7.4). The cell pellet was resuspended in $200 \mu \mathrm{L}$ of PBS. Total purified genomic bacterial DNA was extracted with a genomic DNA mini kit (QiAgen, DNeasy ${ }^{\circledR}$, USA) according to manufacturer's instruction. All the extracted DNA of the standard strains and of the sample isolates were examined using multiplex PCR for molecular typing of the virulence genes $(r f b E$, st $x 1, s t x 2, f l i C)$ using spesific nucleotide primers are listed in Table 1 (Hu et al., 1999). Amplification condition was carried out according to Inat and Siriken (2010) with a modification. The reaction mixture consisted of $4.8 \mu \mathrm{L}$ of aquadest (DNAse, RNAse free), $10 \mu \mathrm{L}$ of Maxima hot start green PCR master mix (2x) (Thermo Scientific ${ }^{\mathrm{TM}}$ ), and $0.4 \mu \mathrm{L}$ of each primer.

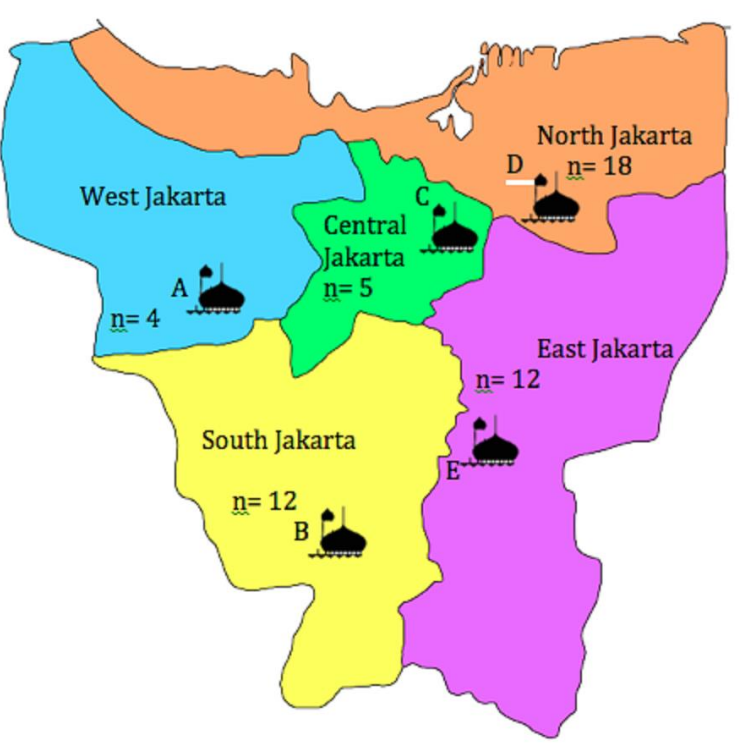

Figure 1. Geographical distribution of mosques A-E in Jakarta from which the samples were collected. Total number of samples $=51$. 
Temperature conditions consisted of an initial $95^{\circ} \mathrm{C}$ denaturation step for $4 \mathrm{~min}$ followed by 35 cycles of $95^{\circ} \mathrm{C}$ for $30 \mathrm{~s}, 50^{\circ} \mathrm{C}$ for $30 \mathrm{~s}$, and $72^{\circ} \mathrm{C}$ for $1 \mathrm{~min}$. The final cycle was followed by 1 cycle at $72^{\circ} \mathrm{C}$ for $5 \mathrm{~min}$ in the thermal cycling system. Agarose gel electrophoresis was carried out according to Sanam (2015) with minor modification to evaluate the amplified fragments using standard PCR markers.

\section{Antibiotic Susceptibility}

It was determined by the standardized agar diffusion test on MüllerHinton agar (MHA, Difco, USA) using the following disks (Oxoid, UK): erythromycin (15 $\mu \mathrm{g})$, cefepime $(30 \mu \mathrm{g})$, oxacillin $(30 \mu \mathrm{g})$, azithromycin (15 $\mu \mathrm{g})$ and tetracyclines $(30 \mu \mathrm{g})$. Isolates were categorized as susceptible, intermediate and resistant based upon interpretative criteria developed by the guideline of Clinical and Laboratory Standards Institute (CLSI, 2014).

\section{RESULTS}

\section{Characterization of STEC Isolates by Multiplex PCR for $s t x 1, s t x 2, r f b E$ and Flagellar H7 Gene}

As shown in Table 2, two isolates (isolate number 11 and 14) were confirmed as STEC because they all carried st $x$ genes. The isolates $(n=30)$ were also applied to a multiplex PCR assay to confirm the presence of flagellar gene. In flagellar H7 PCR assay, 1 isolate (isolate number 11) was found harboring $\mathrm{H} 7$ genes (Table 2). However, all isolates are lacking the $r f b E$ gene (Table 2).

\section{Antibiotic Resistance}

The antibiotic resistance profiles of the STEC isolates against 5 antimicrobial agents are presented in Table 3, respectively. The results indicated that E. coli and STEC isolated from qurban festival in Jakarta were resistant to erythromycin $(100 \%)$ and oxacillin $(100 \%)$ (Figure 2). Resistance to cefepime, azithromycin, and tetracycline was rare.

\section{DISCUSSION}

In this study, 2 of STEC were detected in meat and feces samples as shown in Table 2. Meat sample (5.3\%) and feces sample $(8.3 \%)$ showed st $x 1$ gene and st $x 2$ gene in multiplex PCR (Figure 3), respectively. No STEC was detected in the liver samples. Ruminants are considered as an important source of STEC and cattle were identified as the primary reservoir of STEC (Akanbi et al., 2011). Intestinal carriages of STEC in ruminants cause fecal shedding and the release of STEC into the environment (Forano et al., 2013).

The non-O157 populations of E. coli have been shown to vary in their distribution among bovine and clinical sources (Borgatta et al., 2012). In the study, all isolates were lacking $r f b E$ gene, which is well known as characteristic of 0157 strains. On the other hand, gene flic, a characteristic of H7 strain was detected. From 51 isolates, $1(8.3 \%)$ isolate was confirmed the presence of fliC genes i.e isolates no. 11 in feces sample. The pathogenic potential of STEC isolates has also been shown to be associated with the presence of Stx genotypes (Rahal

Table 2. Results of multiplex PCR

\begin{tabular}{lcccc}
\hline Samples & $\begin{array}{c}r f b E \text { gene } \mathrm{n} \\
(\%)\end{array}$ & $\begin{array}{c}f l i C \text { gene } \mathrm{n} \\
(\%)\end{array}$ & $\begin{array}{c}\text { stx1 gene } \mathrm{n} \\
(\%)\end{array}$ & $\begin{array}{c}\text { stx2 gene } \mathrm{n} \\
(\%)\end{array}$ \\
\hline $\begin{array}{l}\text { Meat } \\
(\mathrm{n}=19)\end{array}$ & $0(0)$ & $0(0)$ & $1(5.3)$ & $0(0)$ \\
$\begin{array}{l}\text { Liver } \\
(\mathrm{n}=20)\end{array}$ & $0(0)$ & $0(0)$ & $0(0)$ & $0(0)$ \\
$\begin{array}{l}\text { Feces } \\
(\mathrm{n}=12)\end{array}$ & $0(0)$ & $1(8.3)$ & $0(0)$ & $1(8.3)$ \\
Total & $0(0)$ & $1(8.3)$ & $1(5.3)$ & $1(8.3)$ \\
\hline
\end{tabular}

Table 3. Antibiotic resistance profiles of the STEC non O157

\begin{tabular}{clcc}
\hline $\begin{array}{c}\text { Isolate } \\
\text { number }\end{array}$ & \multicolumn{1}{c}{$\begin{array}{c}\text { Antimicrobial } \\
\text { agent }\end{array}$} & $\begin{array}{c}\text { Diameter of } \\
\text { killing zone } \\
(\mathrm{mm})\end{array}$ & $\begin{array}{c}\text { Interpretative } \\
\text { criteria }\end{array}$ \\
\hline \multirow{4}{*}{11} & Erythromycin & 0 & $\mathrm{R}$ \\
& Cefepime & 23 & $\mathrm{~S}$ \\
& Oxacillin & 0 & $\mathrm{R}$ \\
& Azithromycin & 23 & $\mathrm{~S}$ \\
& Tetracycline & 24 & $\mathrm{~S}$ \\
& Erythromycin & 0 & $\mathrm{R}$ \\
& Cefepime & 24 & $\mathrm{~S}$ \\
& Oxacillin & 0 & $\mathrm{R}$ \\
& Azithromycin & 21 & $\mathrm{~S}$ \\
& Tetracycline & 18 & $\mathrm{~S}$ \\
\hline
\end{tabular}

Note: R (Resistant), S (Susceptible)

Table 1. Primer sequences used in the multiplex PCR assay and the expected sizes of the products

\begin{tabular}{|c|c|c|c|}
\hline Target gene & Size (bp) & Primer & Sequence \\
\hline \multirow[t]{2}{*}{$r f b E$} & 292 & $\mathrm{RfbF}$ & 5'-GTGTCCATTTATACGGACATCCATG-3' \\
\hline & & RfbR & 5'-CCTATAACGTCATGCCAATATTGCC-3' \\
\hline \multirow[t]{2}{*}{ fliC } & 625 & FLICh7-F & 5'-GCGCTGTCGAGTTCTATCGAGC-3' \\
\hline & & FLICh7-R & 5'-CAACGGTGACTTATCGCCATTCC-3' \\
\hline \multirow[t]{2}{*}{ stx1 } & 210 & SLT-IF & 5'-TGTAACTGGAAAGGTGGAGTATAC-3' \\
\hline & & SLT-IR & 5'-GCTATTCTGAGTCAACGAAAAATAAC-3' \\
\hline \multirow[t]{2}{*}{$s t x 2$} & 484 & SLT-IIF & 5'-GTTTTTCTTCGGTATCCTATTCCG-3' \\
\hline & & SLT-IIR & 5'-GATGCATCTCTGGTCATTGTATTAC-3' \\
\hline
\end{tabular}




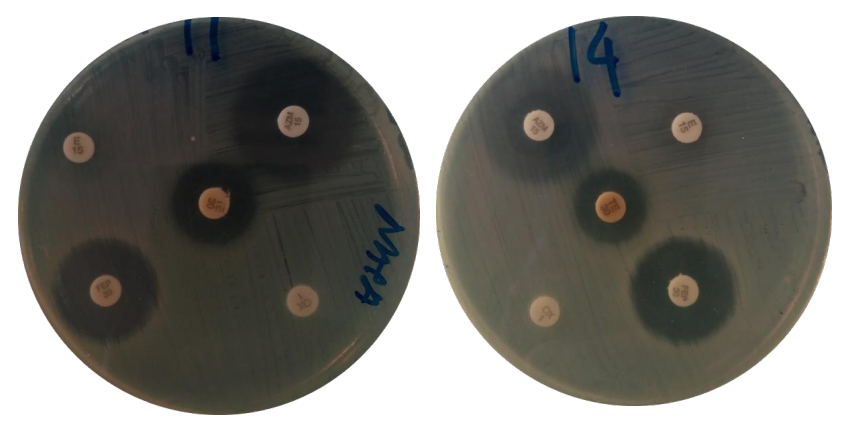

Figure 2. The killing zone performed by STEC non-O157 (left; isolate number 11) (right; isolate number 14)

et al., 2012). In this study, one STEC isolate produced Stx2 i.e isolate no. 11 in feces sample. Stx 2 are known to be more toxic and are more often associated with $\mathrm{HC}$ or HUS in human infections than Stx1 (Etienne-Mesmin et al., 2011; Lim et al., 2010; Melton-Celsa et al., 2012). One isolate obtained from meat of an animal investigated in the present study was positive for Stx1. In this study, STEC O-H7 isolate carried Stx2 indicating the high pathogenic potential for human. Previous study (Koitabashi et al.; 2006) also suggested that Stx2 positive E. coli seem to be widely distributed in the Asian environment. This finding implies that humans were now exposed to STEC non-O157 from food of animal origin. Despite STEC non-O157 have lower virulence, this strain may be capable of causing disease when a high inoculum is ingested or in particularly susceptible individuals.

According to Gould et al., (2013); Luna-Gierke et al. (2014), the number of reported STEC nonO157 infections increased in the United States recently. In Indonesia, the case reports are not well established. However, nephrotic syndrome is one of the most frequent glomerular diseases seen in children. Approximately, there are six case of NS per year for every 100,000 child aged less than 14 years old in Indonesia (Mamesah et al., 2016). Interestingly, the etiology is unknown.

In this study, the antibiotic resistance profiles of two STEC isolates against 5 antimicrobial agents are presented in Table 3. These findings showed the STEC isolates were $100 \%$ of resistance to erythromycin and oxacillin. Meanwhile, previous study found E. coli pathogen were resistant to streptomycin, chloramphenicol, sulfamethoxazole and gentamicin (Nugraha et al. 2013). Currently, the treatment of STEC infections with antibiotics is controversial (Pacheco \& Sperandio 2012). However, many clinicians still used antimicrobial therapy as an option for the treatment of STEC infection. Thus, the use of oxacillin and erythromycin both in human and animals may select for resistance among STEC. The presest study provides initial data for the presence of STEC non-O157 in Qurban festival in Jakarta. These findings might help to lessen the risk of transmission of STEC non-O157 in public health.

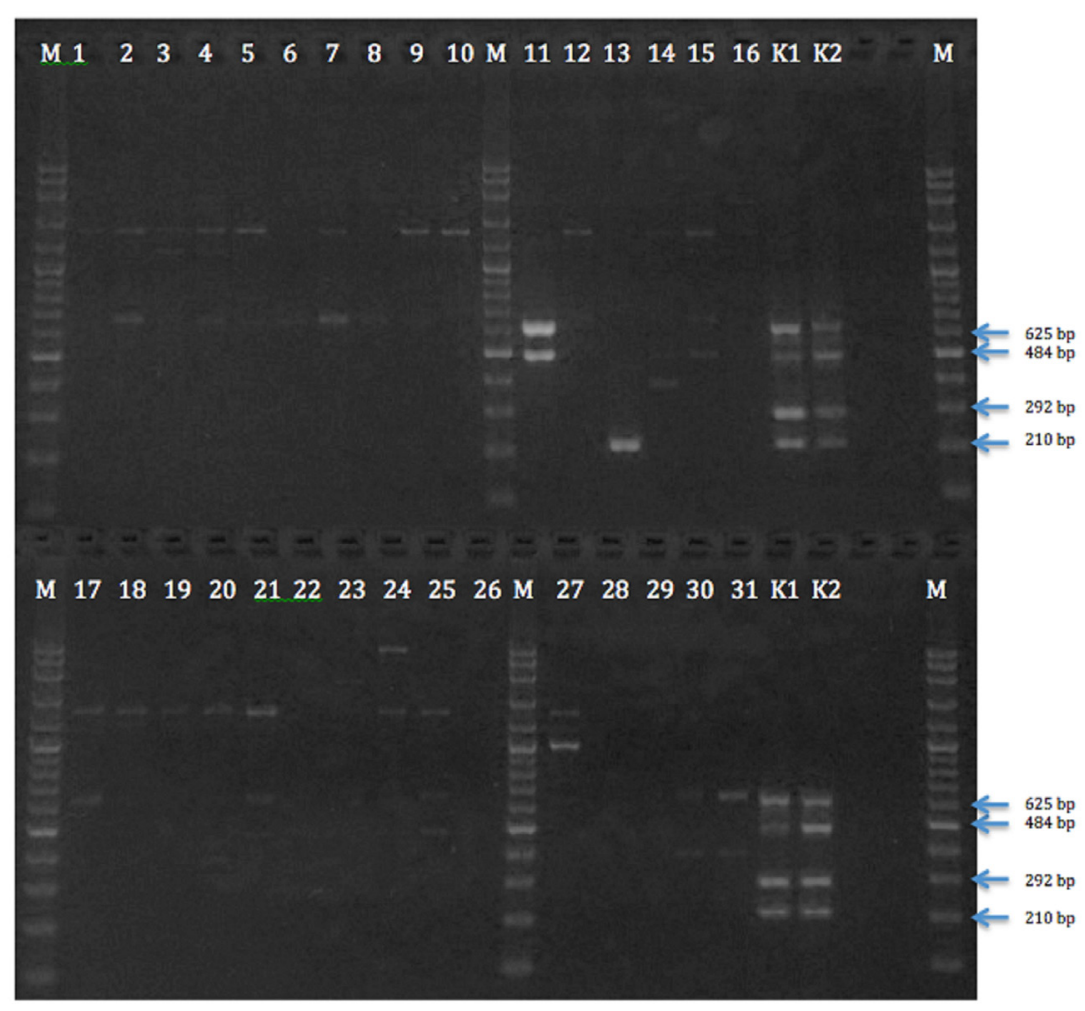

Figure 3. The determination of $r f b E(\mathrm{O} 157)$, stx1, stx2, fliC (H7) genes of E. coli by multiplex PCR. Lane M: Marker (100 3,000 bp), Lane K1: positive control (E. coli O157:H7 35150), Lane K2: positive control (E. coli 1-AN), Lanes 1 to 31: samples isolated from qurban animal origin. 


\section{CONCLUSION}

STEC non-O157 was detected in feces $(8.3 \%)$ and meat $(5.3 \%)$ both isolated from cattle slaughtered in Qurban festival. However, no STEC were found in the liver. In antimicrobial susceptibility tests, the STEC isolates showed antibiotic resistance to erythromycin and oxacillin. The result showed that meat and feces of this origin activity represents a potential risk to human health.

\section{ACKNOWLEDGEMENT}

This work was supported by Ristek Dikti (Ministry of Research, Technology and High Education) through PMDSU (Program Magister Menuju Doktor untuk Sarjana Unggulan) 2013-2017, Indonesia.

\section{REFERENCES}

Akanbi, B. O., I. P. Mbah, \& P. C. Kerry. 2011. Prevalence of Escherichia coli $\mathrm{O} 157: \mathrm{H} 7$ on hides and faeces of ruminants at slaughter in two major abattoirs in Nigeria. Lett. Appl. Microbiol. 53: 336-340. http://dx.doi.org/10.1111/j.1472765X.2011.03113.X

Borgatta, B., N. Kmet-Lunaček, \& J. Rello. 2012. E. coli O104:H4 outbreak and haemolytic-uraemic syndrome. Med. Intensiva. 36: 576-583. http://dx.doi.org/10.1016/j.medin.2011.11.022

[CLSI] Clinical and Laboratory Standards Institute. 2014. Performance standards for antimicrobial susceptibility testing; twenty-fourth informational supplement. CLSI document M100-S24. 34 (1): 50-57.

Etienne-Mesmin, L., B. Chassaing, P. Sauvanet, J. Denizot, S. Blanquet-Diot, A. Darfeuille-Michaud, N. Pradel, \& V. Livrelli. 2011. Interactions with $\mathrm{M}$ cells and macrophages as key steps in the pathogenesis of enterohemorragic Escherichia coli infections. PLoS One. 6: e23594. http://dx.doi. org/10.1371/journal.pone.0023594

Forano, E., F. Chaucheyras-Durand, Y. Bertin, \& C. Martin. 2013. EHEC carriage in ruminants and probiotic effects. Biol. Aujourdhui. 207: 261-267. http://dx.doi.org/10.1051/ jbio/2013023

Frank, C., D. Werber, J. P. Cramer, M. Askar, \& M. Faber. 2011. Epidemic Profile of Shiga-Toxin-Producing. N. Engl. J. Med. 1771-80. doi:10.1056/NEJMoa1106483. http://dx.doi. org/10.1056/NEJMoa1106483

Luna-Gierke, R. E., P. M. Griffin, L. H Gould., K. Herman, C. A. Bopp, N. Strockbine, \& R. K. Mody. 2014. Outbreaks of non-O157 Shiga toxin-producing Escherichia coli infection: USA. Epidemiology and Infection. 142: 2270-2280. http:// dx.doi.org/10.1017/s0950268813003233

Gould, L. H., R. K. Mody, K. L. Ong, P. Clogher, A. B. Cronquist, K. N. Garman, S. Lathrop, C. Medus, N. L. Spina, T. H. Webb, P. L. White, K. Wymore, R. E. Gierke, B. E. Mahon, \& P. M. Griffin. 2013. Increased recognition of non-o157 shiga toxin-producing Escherichia coli infections in the United States during 2000-2010: epidemiologic features and comparison with E. coli o157 infections. Foodborne Pathogens and Disease. 10: 453-460. http://dx.doi. org/10.1089/fpd.2012.1401

Hu, Y., Q. Zhang, \& J. C. Meitzler. 1999. Rapid and sensitive detection of Escherichia coli O157:H7 in bovine feces by a multiplex PCR. J. Appl. Microbiol. 87: 867-876. http://dx.doi. org/10.1046/j.1365-2672.1999.00938.x

Inat, G. \& B. Siriken. 2010. Detection of Escherichia coli O157 and Escherichia coli O157:H7 by the immunomagnetic separation technique and $s t x 1$ and $s t x 2$ genes by multiplex PCR in slaughtered cattle in Samsun Province, Turkey. J. Vet. Sci. 11: 321-326. http://dx.doi.org/10.4142/jvs.2010.11.4.321

Koitabashi, T., V. Vuddhakul, \& S. Radu. 2006. Genetic characterization of Escherichia coli O157: H7-strains carrying the st $x 2$ gene but not producing Shiga toxin 2. Microbiol. Immunol. 50: 135-148. http://dx.doi.org/10.1111/j.1348-0421.2006. tb03779.x

Kundu, D., A. Gill, C. Lui, N. Goswami, \& R. Holley. 2014. Use of low dose e-beam irradiation to reduce E. coli O157:H7, non-O157 (VTEC) E. coli and Salmonella viability on meat surfaces. Meat Sci. 96: 413-418. http://dx.doi.org/10.1016/j. meatsci.2013.07.034

Lim, J. Y, J. W Yoon, \& C. J. Hovde. 2010. A brief overview of Escherichia coli O157:H7 and its plasmid O157. J. Microbiol. Biotechnol. 20: 5-14.

Mamesah, R. S., A. Umboh, \& S. Gunawan. 2016. Hubungan aspek klinis dan laboratorium dengan tipe sindrom nefrotik pada anak. ECL. 4: 1-5.

Melton-Celsa, A., K. Mohawk, L. Teel, \& A. O'Brien. 2012. Pathogenesis of Shiga-Toxin Producing Escherichia coli. Curr. Top. Microbiol. Immunol. 357: 67-103. http://dx.doi. org/10.1007/82_2011_176

Nugraha, A., N. K. Besung, \& H. Mahatmi. 2013. Sensitivity of pathogenic E. coli isolated from pigs with colibacillosis to antibiotics at the district of Kerambitan and Tabanan, the Regency of Tabanan, Bali. Jurnal Ilmu dan Kesehatan Hewan. 1: 34-39.

Nguyen, Y. \& V. Sperandio. 2012. Enterohemorrhagic E. coli (EHEC) pathogenesis. Front. Cell. Infect. Microbiol. 2: 90. http://dx.doi.org/10.3389/fcimb.2012.00090

Pacheco, A. R. \& V. Sperandio. 2012. Shiga toxin in enterohemorrhagic E. coli: regulation and novel anti-virulence strategies. Front. Cell. Infect. Microbiol. 2: 1-12. http://dx.doi. org/10.3389/fcimb.2012.00081

Perera, A., C. M. Clarke, G. A. Dykes, \& N. Fegan. 2015. Characterization of Shiga Toxigenic Escherichia coli O157 and Non-O157 Isolates from Ruminant Feces in Malaysia. Biomed. Res. Int. 382403.

Rahal, E. A., N. Kazzi, F. J. Nassar, \& G. M. Matar. 2012. Escherichia coli O157:H7-Clinical aspects and novel treatment approaches. Front. Cell. Infect. Microbiol. 2: 138. http:// dx.doi.org/10.3389/fcimb.2012.00138

Sanam, M. U. E., W. Asmara, A. E. T. H. Wahyuni, M. H. Wibowo, \& R. S. Adji. 2015. Polymerase chain reaction multiplex to evaluate the virulence status of Bacillus anthracis isolates from Nusa Tenggara and Papua. Jurnal Kedokteran Hewan. 9: 89-93.

Selim, S. A., S. F. Ahmed, M. H. A. Aziz, A. M. Zakaria, J. D. Klena, \& D. Pangallo. 2013. Prevalence and characterization of shiga-toxin O157:H7 and non-O157:H7 enterohemorrhagic Escherichia coli isolated from different sources. Biotechnol. Equip. 27: 3834-3842. http://dx.doi. org/10.5504/BBEQ.2013.0031

Sharma, V. K. 2006. Real-time reverse transcription-multiplex PCR for simultaneous and specific detection of $\mathrm{rfbE}$ and eae genes of Escherichia coli O157:H7. Mol. Cell. Probes. 20: 298-306. http://dx.doi.org/10.1016/j.mcp.2006.03.001

Torres, A. G., Y. Li, C. B. Tutt, L. Xin, T. Eaves-Pyles, \& L. Soong. 2006. Outer membrane protein a of Escherichia coli O157:H7 stimulates dendritic cell activation. Infect. Immun. 74: 2676-2685. http://dx.doi.org/10.1128/ IAI.74.5.2676-2685.2006

Wang, G., T. Zhao, \& M. P. Doyle. 1996. Fate of enterohemorrhagic Escherichia coli O157:H7 in bovine feces. Applied and Environmental Microbiology. 62: 2567-2570.

Xicohtencatl-cortes, J., V. Monteiro-Neto, M. A. Ladesma, D. M. Jordan, O. Francetic, J. B. Kaper, J. L. Puente, \& J. A. Giron. 2007. Intestinal adherence associated with type IV pili of enterohemorrhagic Escherichia coli O157 :H7. J. Clin. Invest. 117: 21-24. http://dx.doi.org/10.1172/JCI30727 